\title{
Chapter 11 \\ Recruitment of Dry Forest Tree Species in Central Brazil Pastures
}

\author{
Aldicir Scariot, Daniel L. M. Vieira, Alexandre B. Sampaio, \\ Ernestino Guarino and Anderson Sevilha
}

\subsection{Introduction}

Despite its importance as a wealthy source of unique biodiversity (Janzen 1988) and that it covers $42 \%$ of the tropical vegetation worldwide (Murphy and Lugo 1995), the dry forest is the most endangered terrestrial ecosystem and one of the least protected (Scariot and Sevilha 2005). In Central America for example, less than $1 \%$ of the original $500,000 \mathrm{~km}^{2}$ is preserved in conservation units (Janzen 1988, Sanchez-Azofeifa et al. 2003). In Brazil, the seasonal deciduous forests - a type of dry forest-covers $27,367,815$ ha $(3.21 \%)$ of the territory, from which 1,072,946 ha $(3.9 \%)$ are protected by conservation units. Among conserved areas of deciduous dry forest, only 117,980 ha $(0.43 \%)$ are in conservation units of restricted use as national parks and biological reserves. Most of the conservation units $(402,456$ ha or $1.47 \%$ ) allow limited economic use of the land and natural resources. There is no information of the conservation unit assigned in official database for 552,509 ha (2.02\%) of dry forests (Sevilha et al. 2004).

Dry forests occur in many soil classes. In Brazil they occur in at least 13 soil classes of the Brazilian Soil Classification (Scariot and Sevilha 2005), but deciduous dry forests occur predominantly in rich soils. There are many valuable trees used for timber. These forests are the main targets of farmers, who log the trees and sell the timber to acquire financial resources to establish farms. In Central Brazil, where some of the most important remnants of dry forests of the country occur (Fig. 11.1), most of the area originally occupied by dry forests has been replaced by pasture composed by exotic grass in extensive farmlands on rich soils.

Recommendations have been made for the creation of new conservation units, but given the high degree of landscape fragmentation any new conservation unit will contain significant proportion of its area covered by pasture and forest fragments with different levels of disturbance caused by logging, cattle grazing, fire and invasive species. Thus, in this scenario it is fundamental to understand the mechanisms of tree regeneration in pasture fields to address vegetation recovery and use this information to facilitate forest regeneration.

There are four to five times more studies on the natural regeneration of rainforests than on dry forests, and even less on restoration (Vieira and Scariot 2006a). Taking into account the threat level, the lack of conservation units, the lack of information 


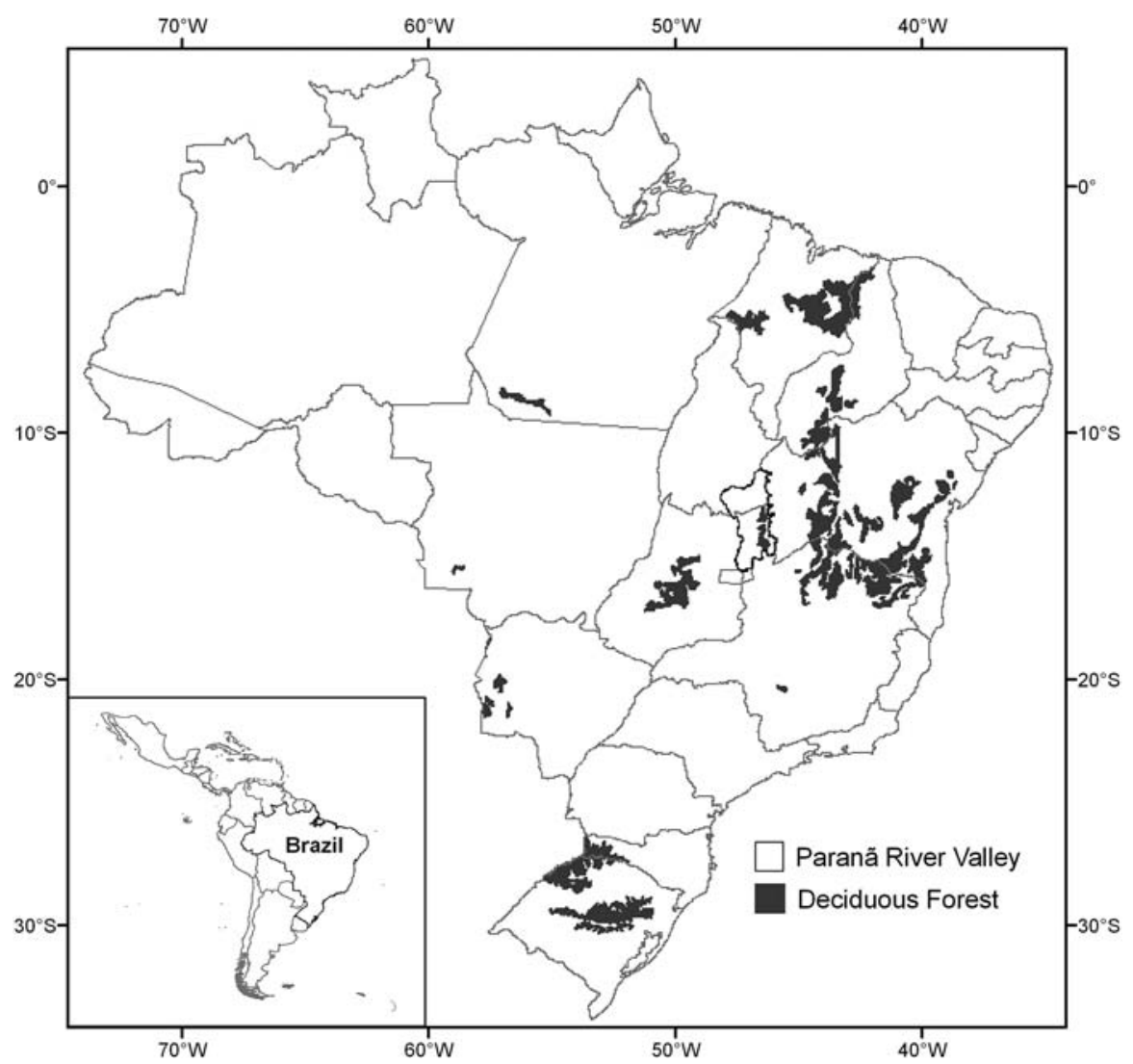

Fig. 11.1 Map of Brazil showing the distribution of the deciduous forests (shaded areas) and the location of the Paranã River Valley in Central Brazil

on regeneration mechanisms, and understanding how regeneration can be enhanced are crucial concerns for the conservation, restoration and management of the dry forests.

\subsection{The Case of Paranã River Valley in Central Brazil}

The Paranã River valley has an area of $59,403 \mathrm{~km}^{2}$ in the Cerrado biome. It is embedded in a transition zone between the wet Amazon region and the semi-arid Caatinga region. It has a Tropical climate with two well defined seasons (AW of Köppen) varying to Cwa (Altitude Tropical Climate) (IBGE 1995).

This region presents a mosaic of vegetation types, and has some of the last remnants of seasonally deciduous forests in Brazil. These occur from 400-600 $\mathrm{m}$ above sea level, with annual precipitation of $1,236 \mathrm{~mm} \pm 255$ (SD, data from 1969 to 1994). 89\% of the rains fall between October and March. The mean annual 
temperature is $23^{\circ} \mathrm{C}$, fairly constant throughout the year. The landscape is flat and consists of limestone geology, with occasional limestone outcrops containing a moderately distinct tree flora (Silva and Scariot 2003). Nitosoil is the main soil class upon flat to lightly rugged (Krejci et al. 1982). Rocky limestone outcrops are common in the region.

This basin is between two well known vascular plant distribution patterns in Brazil. One of them is formed by forest species with different levels of leaf shedding that depend mainly on the presence of fertile soils within the Cerrado domain and occurs mainly in the northeast-southeast arch, connecting the Caatinga to the Chaco border. The other pattern is formed by species from the Amazon and Atlantic rainforests, crossing the Cerrado biome through riparian forests (Oliveira-Filho and Ratter 1995).

On the flat lands, the forest canopy is $17-23 \mathrm{~m}$ height with a basal area of 23$28 \mathrm{~m}^{2} /$ ha (Scariot and Sevilha 2005). The authors found 128 tree species in 90 genera and 41 families. Most species are commonly found in large Brazilian biomes such as Cerrado, Caatinga, Amazonia and Atlantic Forest (Scariot and Sevilha 2005). Cattle farming, logging and incipient agriculture are the main economic activities of the region. Wood has been harvested mainly for corral and fence building, for the production of woodchip, and for civil construction. The main exploited species are Astronium fraxinifolium Schott, Myracrodruon urundeuva Fr. All., Schinopsis brasiliensis Engl. and Tabebuia impetiginosa (Mart. ex DC.) Standl., which have been commercialized locally, regionally and also in the Southern Brazilian markets (IBGE 1995).

This region has been acknowledged for biodiversity conservation efforts by Brazilian researchers and the Government (Brasil 2002). However, despite its importance, the region is dominated by cattle farms and forest fragments rarely exceeding 250 ha (Andahur 2001). There are three conservation units, but only the smallest one, with less than 2,000 ha, is fully implemented.

\subsection{Seed Germination in Pastures}

Seed dispersal is the main barrier for plant recruitment on abandoned pastures (Holl 1999, Holl et al. 2000, Wijdeven and Kuzee 2000), but it can be overcome either by direct seeding (Engel and Parrotta 2001, Camargo et al. 2002, Doust et al. 2006) or by installation of bird perching (Melo et al. 1997, Holl 1998, Duncan and Chapman 1999, Melo et al. 2000). However, after sowing germination can also be highly limited by (1) seed predation (Nepstad et al. 1996, Holl and Lulow 1997, Jones et al. 2003, Myster 2003, 2004a,b); (2) competition with exotic grasses (Desteven 1991, Holl 1999, Holl et al. 2000) and (3) water shortage (Lieberman and Li 1992, Ray and Brown 1995), and (4) pathogens (Myster 1997, 2004a). The relative importance of each factor varies widely among species and studied areas (Holl 1999).

Although studies are scarce, seed predation has been found to have high impact on seed germination of dry forest species in pastures in Central Brazil (Vieira and Scariot 2006b), similarly to findings from other tropical regions (Nepstad et al. 1996, 
Camargo et al. 2002, Myster 2004a,b). The intensity of seed predation is highly dependent on the seed species (Osunkoya 1994, Holl and Lullow 1997). Medium sized seeds $(0.2-4 \mathrm{~g})$ are usually more susceptible to rodents, since they are easier to find and they are easier to manipulate than larger seeds (Price and Jenkins 1986, Nepstad et al. 1990, Osunkoya 1994, but see Hammond 1995, Holl and Lulow 1997 for different results). Less rodent abundance in pastures may result in less mediumsize seed predation than in forests (Jones et al. 2003, Meiners and LoGiudice 2003). Small seeds are eaten mainly by insects, such as ants (Nepstad et al. 1990, 1996, Osunkoya 1994), resulting in higher predation of small seeds in pastures (Nepstad et al. 1990 1996, Duncan and Duncan 2000, Jones et al. 2003). From 6 tree species studied in active pastures of Central Brazil dry forests, the small seeded Tabebuia impetiginosa $(0.11 \mathrm{~g})$ and Astronium fraxinifolium Schott ex Spreng. (0.02g) were highly preyed or removed, mostly by ants (Tabebuia: 50\% and Astronium: 28\%), when compared to seeds dispersed in forest remnants. In recently abandoned pastures, small seeds are preyed and removed at rates varying from 46-73\% under grass cover, although one species, Guazuma ulmifolia experiences only $1 \%$ of seed loss (Guarino 2004). The large seeded (>7.5g) Cavanillesia arborea (Willdenow) K. Schum. and Swartzia multijuga Vogel, had over $90 \%$ predation by cattle in pastures (Vieira and Scariot 2006b).

Harsh climatic conditions during the dry season and dry spells in the wet season can be critical for seed survival in dry forest regions (Gerhardt 1994, Ray and Brown 1995, McLaren and McDonald 2003). Desiccation killed ca. 75\% of the thin-coated and high water-containing seeds of Swartzia multijuga and Eugenia dysenterica DC. in the pasture (Vieira and Scariot 2006b). A small amount of shade in the forests, however, was enough to prevent seed desiccation. Small seeds with low water content and small mass can survive the harsh environmental conditions of pastures (Vieira and Scariot 2006b). In the wet season, grasses maintain soil moisture to the same levels found under deciduous dry forests canopy (22-23\%) thus contributing to a significant increase in seed germination in 6 out of 12 tree species in Central Brazil pastures (Guarino 2004). Three species (Cedrela fissilis, Amburana cearensis and Sterculia striata) showed increases in seed germination by 2 to 10 fold under grass cover (Fig. 11.2).

Pathogen attack was also a significant source of seed mortality, mostly for Aspidosperma pyrifolium. A. pyrifolium and Tabebuia impetiginosa experienced high pathogen attack in greenhouse seedlings, mainly in most shaded conditions (Vieira 2006). Even though this is well known for rain forest species (e.g. Augspurguer 1983, Dalling et al. 1998), seed mortality by pathogens has been recently reported for dry forest species as well (Grogan and Galvão 2006, Vieira and Scariot 2006b). Despite the lack of information, it has been reported that Fusarium and Colletotrichum fungi are the second most important seed mortality agents in abandoned pastures and early succession areas in Puerto Rico and Ecuador (Myster 1997, 2004a). However, fungi from Phoma and Phyllosticta genera and Colletotrichum gloeosporioides although abundant on Inga and Cecropia schreberiana respectively, resulted in modest seedling leaf loss (Myster 2002).

The use of direct seeding in pastures must consider that adequate species choice and seeding time are fundamental for restoration success. In the Paranã River Valley 

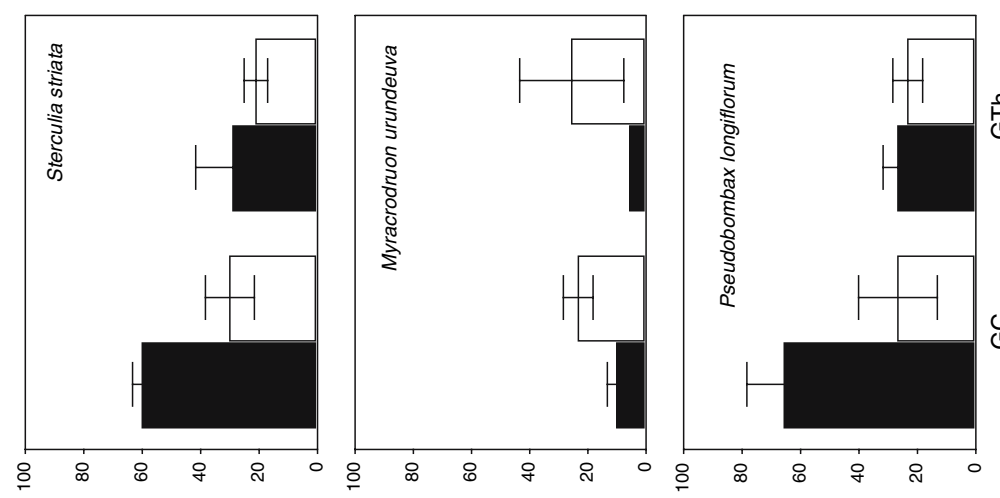

疍
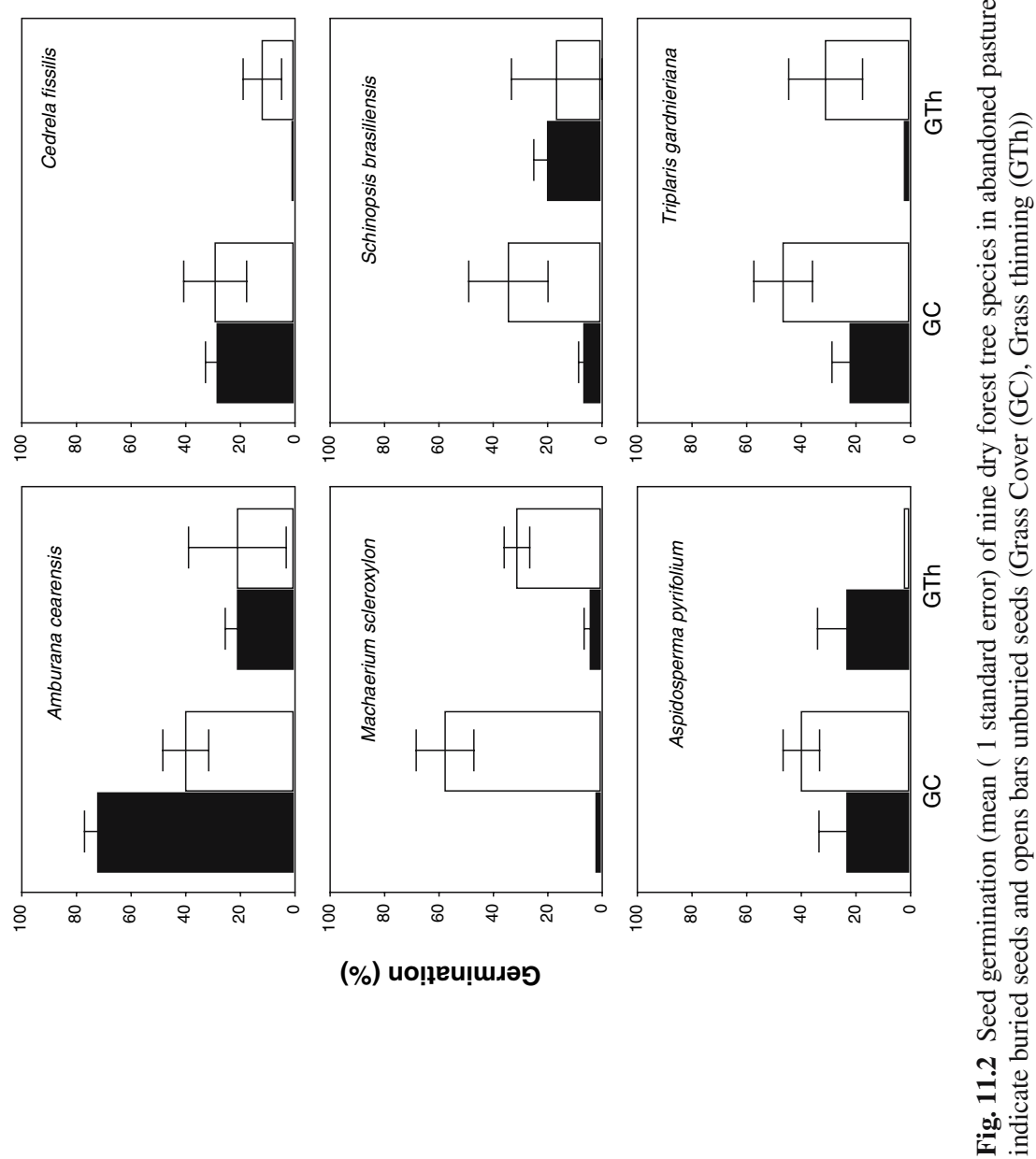

(\%) иo!̣eu!̣มәэ 
dry forests, priority must be given to species with seeds with small mass and low water content that can tolerate the harsh environmental conditions found in early successional stages and are less affected by predation and removal.

The positive effect of grass cover on seed germination must be further explored to better understand seedling establishment and growth. Burying seeds instead of disposing them on the soil surface, seems to be a good strategy to decrease mortality by predation (Woods and Elliott 2004) and desiccation (Negreros-Castillo et al. 2003) in agricultural lands previously covered by dry forests and degraded soils (Doust et al. 2006). However, Guarino (2004) found contradictory results, highlighting that this issue deserves further investigation.

\subsection{Seedling Establishment}

Several factors have been indicated to restrict the establishment of forest tree seedlings in pastures. These factors can act differently in germination and seedling establishment processes (Schupp 1995). For instance, some species can germinate under grass cover but will not develop due to grass competition (Zimmerman et al. 2000, Holl 2002). Herbivory by wild (Nepstad et al. 1996, Holl and Quiros-Nietzen 1999, Sweeney et al. 2002) or domestic animals (Posada et al. 2000) have been considered to affect seedling establishment in pastures. Other factors include limited water and nutrient availability (Aide and Cavelier 1994, Nepstad et al. 1996), competition with exotic or invasive plants (Holl 2002, Sweeney et al. 2002, Hau and Corlett 2003), high light availability, high air and soil temperatures (Nepstad et al. 1996, Loik and Holl 1999, Alvarez-Aquino et al. 2004) and soil compaction (Nepstad et al. 1996). Among these, grass competition is considered to be the most limiting, especially in tropical rain forest regions (Holl et al. 2000). Compared to forest environments, the establishment of seedlings in pastures is considerably reduced (Aide and Cavelier 1994, Nepstad et al. 1996, Alvarez-Aquino et al. 2004).

In two abandoned pastures originally covered by seasonal deciduous forests in Central Brazil, tree seedling survival was low but apparently was not related to grass competition. Despite the low survival, thinning the grass cover of Andropogon gayanus Kunth. did not interfered on the survival of 6 out of 7 species of planted tree seedlings after 14 months (Fig. 11.3). Some grass species which develop in tussocks, such as A. gayanus, leave bare soil patches, covered by a canopy of grass leaves, in between the grass tussocks. In the water deficient ecosystem of dry forests, grass canopy improves the microclimate allowing germination and establishment of tree seedlings in between the grass tussocks (Aide and Cavelier 1994, Guarino 2004). Pasture temperature is higher in plots where the grass cover is cleared (Gerhardt 1996, Zimmerman et al. 2000). Therefore the cooler and moister environment created by the grass cover seems to balance the negative effects of grass competition (Gerhardt 1996).

The benefits of grass cover might be even higher than the possible negative effects of grass competition. One of the 7 planted species in abandoned pastures in Central Brazil, Talisia esculenta (A. St.-Hil.) Radlk., had lower survival for grass thinning 


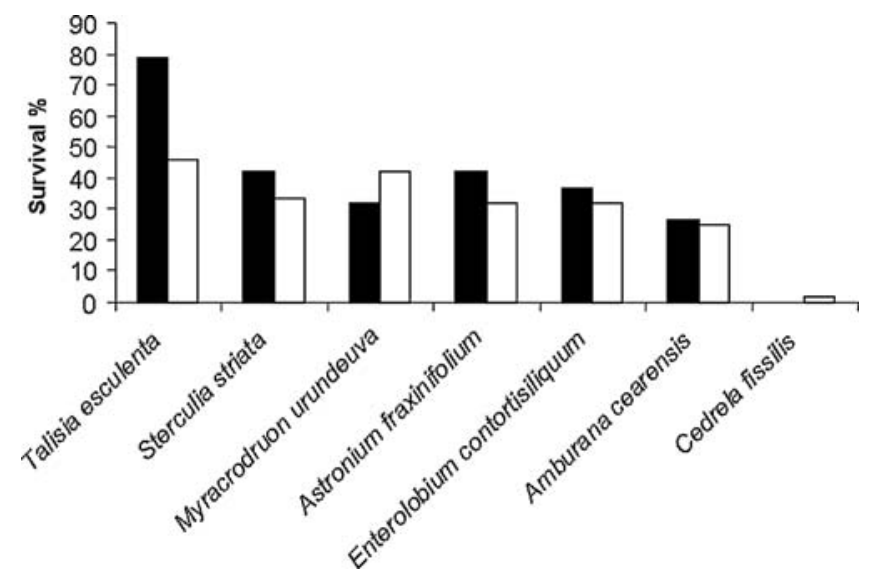

Fig. 11.3 Percentage survival after 14 months of planting of tree seedlings in two pastures in areas originally covered by Dry Forests (data from both pastures aggregated). Dark bars indicate no grass thinning $(\mathrm{N}=19$ seedlings per species $)$ and open bars indicate grass thinning $(\mathrm{N}=57$ seedlings per species; grass thinning once, twice or four times). The only species that showed significant effect of grass thinning was Talisia esculenta (Pearson Chi-square $=6.4, \mathrm{df}=1, p=0.01$ )

treatment (Fig. 11.3). Talisia esculenta seems to survive less in water stressed conditions of bare soil during the dry season and seems to be able to survive under low light levels created by the grass cover. The soil tends to be moister under the grass canopy (Hooper et al. 2002), allowing higher survival and growth of some tree species than in areas with less grass cover (Aide and Cavelier 1994). In dry forest regions water might be the most limiting resource (Gerhardt 1996, Cabin et al. 2002, Marod et al. 2002) and the grass cover in pastures might ameliorate the water deficit for tree regeneration (Aide and Cavelier 1994, Gerhardt 1996). The removal of dominating shrubs in a deforested seasonal moist evergreen forest in Uganda affected tree regeneration in a negative way, indicating possible facilitation interactions between trees and shrubs (Duncan and Chapman 2003). This was similar to the interactions for tree seedlings survival and grass cover found in our studies in Central Brazil. The interactions among grasses and tree regeneration in harsh environments such as pastures in dry forests tend to be more a facilitation relationship rather than competition (Callaway and Walker 1997).

Despite of the apparent positive effect of grass cover on tree seedling survival, seedling growth can be reduced by grass competition (Holl 1998, Hooper et al. 2002, Schaller et al. 2003). A study carried out by Sampaio et al. 2007 in the same region in Central Brazil dry forests that cleared out the grass cover leaving only the naturally established tree regeneration found a higher average increase in height compared to control plots, indicating competition between natural tree regeneration (mostly root-suckers) and grasses. The growth of dry forest tree seedlings planted in greenhouses under different light conditions (10, 40 and $72 \%$ of full sun photon flux density) seems to be higher in the most elevated light levels for the majority of tested species, however seedling survival did not follow a consistent pattern according to the light gradient (Vieira 2006). Grass root system also inhibits tree root 
development resulting in low growth due to grass competition (Putz and Canham 1992, Schaller et al. 2003). In areas with pronounced dry season, grass root competition may have decreased seedling survival and growth. However, clearing out the grass cover (i.e. mowing treatment) can transform pastures in even harsher environments, as detrimental to seedling establishment as grass competition (Hooper et al. 2002).

Light seems to promote seedling growth, and grass cover might out compete tree seedlings creating shadow, inhibiting tree root development and therefore reducing growth. In contrast, low light levels as those created by grass cover may not promote tree seedling survival and some species regeneration may even be facilitated by grass cover. This may indicate water deficit reduction of bare soil of dry forest regions. Therefore, light and water interacting with grass cover seem to be promoting tree seedling establishment at the studied pasture sites in the dry forest regions. These results suggest that seedlings can be introduced in pastures among grass tussocks for pasture restoration (as in A. gayanus pastures in Central Brazil, Sampaio et al. 2007). However, grass cover should be cleared just around the seedlings to improve tree seedling development (Vieira and Scariot 2006a). This will avoid excessive exposure to the plants under harsh conditions.

\subsection{Resprouting Ability}

Root-suckers from trees, shrubs and lianas are found in recently established pastures in tropical forest areas (Uhl et al. 1988, de Rouw 1993, Nepstad et al. 1996). The density of these shoots can be high enough to allow forest regeneration if not eliminated. Actually, shoot elimination by clipping or by use of selective herbicides and root collection after plowing, are common management practices in Central Brazil dry forests region. These practices respond to a large proportion of annual money and labor expenditures in pasture management. Even though farmers battle forest plants exhaustively, many dry forest woody plants persist resprouting many years after pasture establishment (Vieira et al. 2006c, Sampaio et al. in press).

The real contribution of root-suckers relative to seedling establishment for forest regeneration in pastures along tropical forest areas is neglected. To some degree this is due to the laborious work need to detect resprouting which involves digging the superficial soil. The other reason is simply because root-suckers are depleted by sequential cutting, fire, and intensive tractor use (Uhl et al. 1988, de Rouw 1993, Sampaio et al. 1993). Much more attention has been given to evaluate limiting factors and how to improve seed dispersal and survival and seedling survival and growth (reviewed in Holl 2002, Myster 2004b).

Plowing the soil in the middle of the dry season and seeding grass at the beginning of the rainy season is a common practice among farmers of Central Brazil to restore grass cover in pastures. Plowing completely eliminates plant cover, allowing plants to start resprouting soon. Vieira et al. (2006c) investigated the regeneration from root-suckers after plowing in a 10 year-old pasture, a 25 year-old pasture and an early successional forest recently clear cut in Central Brazil dry forests. They 
found that species richness and density were extremely high compared to other disturbed tropical sites with comparable history of land use (e.g. studies by Uhl et al. 1988, Nepstad et al. 1996, Zahawi and Augspurger 1999, Holl et al. 2000). They found 14-182 individuals per $100 \mathrm{~m}^{2}$ of $30-42$ species $(6,5-17,6$ species per $100 \mathrm{~m}^{2}$ ) among the three sites, representing $80 \%$ of the species richness found in intact forest remnants (Vieira et al. 2006c). In another investigation on tree regeneration in active pastures in dry forests of Central Brazil, stem density, regardless of the origin, did not varied with pasture age (from $\leq 6$ up to 40 years old, $n=25$ ), while richness decreased significantly with age (Sampaio et al. in press). Despite the long time since forest removal, pastures still maintained a significant number of dry forest species. The 40 year-old pastures still had 12 dry forest tree species regenerating in relatively high densities (19-58 stems/100 $\mathrm{m}^{2}$, 2nd and 3rd quartiles). Species composition was quite similar among pasture ages and pastures and forest remnants (Vieira et al. 2006c, Sampaio et al. in press), indicating the potential of these areas for dry forest return.

These optimistic results corroborate others findings that dry forest species are strong resprouters and contribute to forest regeneration after disturbance. In other tropical dry forests, studies show a high frequency of resprouting after disturbance (Kennard et al. 2002, McLaren and McDonald 2003). The reasons why resprouting is a particularly important recovery mechanism in dry forests are not certain. Some probable reasons for this trait are (1) seeds have a lower probability of establishment, so the survivorship by resprouting was favored in this forest ecosystem (Ewel 1980); (2) trunk bases are less prone to decay, having more chance to resprout (Ewel 1980); and (3) dry forest plants are adapted for above ground mortality or drought, so they usually resprout (Sampaio et al. 1993, Bond and Midgley 2001).

Although some species are strong resprouters others are not and resprouting ability will depend on the frequency, intensity and duration of the disturbance (Sampaio et al. 1993, Kammesheidt 1999, McLaren and McDonald 2003). Information available from actual literature does not allow one to predict what species are able to resprout in a forest community (Bond and Midgley 2001, Vesk and Westoby 2004). Despite this limitation on the current knowledge it is essential to understand the traits or identities of strong resprouters to be able to (1) help to understand present and future community composition (Kennard 2002, Saha and Howe 2003); (2) use root and branch cuttings of these species as nurse trees in restoration plans; and (3) invest in other restoration mechanisms for weak or non-sprouting species in early successional forests dominated by resprouters.

In dry forests of Central Brazil, species show high density in forest remnants, but that does not happen in ploughed sites (see above in this section; Vieira et al. 2006c). Species with low-density wood such as Cavanillesia arborea and Chorisia pubiflora (A. St.-Hil.) G. Dawson. Spondias mombin L. and Pseudobombax tomentosum (C. Martius and Zuccarini) Robyns, and soft wood species were found only in forest fragments and early successional sites. Species with low-density wood could lose their resprouting ability faster and sometimes did not resprout at all because of decay. In a chronosequence of pasture implementation, most species appear to be able to continue resprouting for up to 11-16 years after disturbance (Sampaio et al. in press). However, in 40 year-old pastures Eugenia dysenterica dominated the 
community, which was poorer in tree species than younger pastures. E. dysenterica occurs in Central Brazil dry forests, but occurs in high frequency in the surrounding savanna vegetation. Species from the Brazilian savannas tend to resprout more than cogeneric species typical from riparian forests in the Cerrado biome, where root systems is not as developed as well as in the dry soils of savannas (Hoffmann et al. 2003). Therefore, savanna species like E. dysenterica that develop deep root system to survive in dry soils of savannas and dry forests might be able to survive longer and even increase its density via vegetative reproduction in pastures. The composition of the secondary vegetation developed in abandoned pastures will be dominated by strong resprouters, probably hard wood and savanna-related species.

Dry forests of Central Brazil show a high degree of resilience after pasture implementation due to root resprouting. Thus, planting seedlings to enhance early succession in abandoned pastures may not be desirable, particularly if standard planting techniques are used. Soil and vegetation disturbances, such as plowing or mechanical hole digging, reduce the density of naturally regenerating trees and consequently slow recovery (Sampaio et al. 2007). Non-resprouting species can be efficiently introduced by cautiously planting nursery-grown seedlings, minimizing damage to natural regeneration. Considering that resprouting ability is positively related to branch cutting success (Itoh et al. 2002), using branch cuttings to improve dry forest recovery should be tested. The rooting ability of branch cuttings was tested, with relative success, for tropical rain forests (Itoh et al. 2002, Zahawi 2005), but we have not found published studies for dry forests. Root cuttings taken from fallen trees from deforested areas may also be tested to enhance dry forest restoration, since planting them is equivalent to root-suckering after plowing.

\section{References}

Aide, T. M., and Cavelier, J. 1994. Barriers to lowland tropical forest restoration in the Sierra Nevada de Santa Marta, Colombia. Restoration Ecology 2(4):219-229.

Alvarez-Aquino, C., Williams-Linera, G., and Newton, A. C. 2004. Experimental native tree seedling establishment for the restoration of a Mexican cloud forest. Restoration Ecology 12(3):412-418.

Andahur, J. P. 2001. Florestas e questões de gestão ambiental na bacia do Rio Paranã. M.Sc. Thesis, Departamento de Engenharia Florestal, Universidade de Brasília, Brasília, DF, Brazil.

Augspurguer, C. K. 1983. Seed dispersal of the tropical tree, Platypodium elegans, and the escape of its seedlings from fungal pathogens. Journal of Ecology 71(3):759-771.

Bond, W. J., and Midgley, J. J. 2001. Ecology of sprouting in woody plants: the persistence niche. Trends in Ecology and Evolution 16(1):45-51.

Brasil. 2002. Biodiversidade Brasileira. Avaliação e identificação de áreas prioritárias para conservação, utilização sustentável e repartição de benefícios da biodiversidade brasileira. Ministério do Meio Ambiente, Brasília.

Cabin, R. J., Weller, S. G., Lorence, D. H., Cordell, S., and Hadway, L. J. 2002. Effects of microsite, water, weeding, and direct seeding on the regeneration of native and alien species within a Hawaiian dry forest preserve. Biological Conservation 104(2):181-190.

Callaway, R. M., and Walker, R. 1997. Competition and facilitation: a synthetic approach to interactions in plant communities. Ecology 78(7):1958-1965.

Camargo, J. L. C., Ferraz, I. D. K., and Imakawa, A. M. 2002. Rehabilitation of degraded areas of central Amazonia using direct sowing of forest tree seeds. Restoration Ecology 10(4):636-644. 
Dalling, J., Swaine, M., and Garwood, N. 1998. Dispersal patterns and seed bank dynamics of pioneer trees in moist tropical forest. Ecology 79(2):564-578.

de Rouw, A. 1993. Regeneration by sprouting in slash and burn rice cultivation, Taï Rain Forest, Côte d'Ivoire. Journal of Tropical Ecology 9(4):387-408.

Desteven, D. 1991. Experiments on mechanisms of tree establishment in old-field succession seedling emergence. Ecology 72(3):1066-1075.

Doust, S. J., Erskine, P. D., and Lamb, D. 2006. Direct seeding to restore rainforest species: Microsite effects on the early establishment and growth of rainforest tree seedlings on degraded land in the wet tropics of Australia. Forest Ecology and Management 234(1-3):333-343.

Duncan, R. S., and Chapman, C. A. 1999. Seed dispersal and potential forest succession in abandoned agriculture in tropical Africa. Ecological Applications 9(3):998-1008.

Duncan, R. S., and Chapman, C. A. 2003. Tree-shrub interactions during early secondary forest succession in Uganda. Restoration Ecology 11(2):198-207.

Duncan, R. S., and Duncan, V. E. 2000. Forest succession and distance from forest edge in an Afro-tropical grassland. Biotropica 32(1):33-41.

Engel, V. L., and Parrotta, J. A. 2001. An evaluation of direct seeding for reforestation of degraded lands in central Sao Paulo state, Brazil. Forest Ecology and Management 152(1-3): $169-181$.

Ewel, J. 1980. Tropical succession: manifold routes to maturity. Biotropica 12(2):2-7.

Gerhardt, K. 1994. Seedling development of four tree species in secondary tropical dry forest in Guanacaste, Costa Rica. Comprehensive Summaries of Uppsala Dissertations from the Faculty of Science and Technology 39. Stockholm, Sweden, Uppsala.

Gerhardt, K. 1996. Effects of root competition and canopy openness on survival and growth of tree seedlings in a tropical seasonal dry forest. Forest Ecology and Management 82(1):33-48.

Grogan, J., and Galvão, J. 2006. Factors limiting post-logging seedling regeneration by big-leaf mahogany (Swietenia macrophylla) in southeastern Amazonia, Brazil, and implications for sustainable management. Biotropica 38(2):219-228.

Guarino, E. S. G. 2004. Germinação de sementes e estabelecimento de plântulas de árvores em florestas estacionais deciduais e pastagens abandonadas. M.Sc. Thesis. Departamento de Ecologia, Universidade de Brasília, Brasília, DF, Brazil.

Hammond, D. S. 1995. Postdispersal seed and seedling mortality of tropical dry forest trees after shifting agriculture, Chiapas, Mexico. Journal of Tropical Ecology 11:295-313.

Hau, B. C. H., and Corlett, R. T. 2003. Factors affecting the early survival and growth of native tree seedlings planted on a degraded hillside grassland in Hong Kong, China. Restoration Ecology 11:483-488.

Hoffmann, W. A., Orthen, B., and do Nascimento, P. K. V. 2003. Comparative fire ecology of tropical savanna and forest trees. Functional Ecology 17:720-726.

Holl, K. D. 1998. Do bird perching structures elevate seed rain and seedling establishment in abandoned tropical pasture? Restoration Ecology 6(3):253-261.

Holl, K. D. 1999. Factors limiting tropical rain forest regeneration in abandoned pasture: Seed rain, seed germination, microclimate, and soil. Biotropica 31(2):229-242.

Holl, K. D. 2002. Tropical moist forest. In Handbook of Ecological Restoration, Vol. II, ed. M. Perrow and A. J. Davy, pp. 539-558 Cambridge: Cambridge University Press.

Holl, K. D., and Lulow, M. E. 1997. Effects of species, habitat, and distance from edge on postdispersal seed predation in a tropical rainforest. Biotropica 29(4):459-468.

Holl, K. D., and Quiros-Nietzen, E. 1999. The effect of rabbit herbivory on reforestation of abandoned pasture in southern Costa Rica. Biological Conservation 87:391-395.

Holl, K. D., Loik, M. E., Lin, E. H. V., and Samuels, I. A. 2000. Tropical montane forest restoration in Costa Rica: Overcoming barriers to dispersal and establishment. Restoration Ecology 8:339-349.

Hooper, E., Condit, R., and Legendre, P. 2002. Responses of 20 native tree species to reforestation strategies for abandoned farmland in Panama. Ecological Applications 12:1626-1641.

IBGE, 1995. Zoneamento geoambiental e agreoecológico do Estado de Goiás: região nordeste. Instituto Brasileiro de Geografia e Estatística/Divisão de geociências do Centro-Oeste, Rio de Janeiro, Brasil, p. 178. 
Itoh, A., Yamakura, T., Kanzaki, M., Ohkubo, T., Palmiotto, P. A., LaFrankie, J. V., Kendawang, J. J., and Lee, H. S. 2002. Rooting ability of cuttings relates to phylogeny, habitat preference and growth characteristics of tropical rainforest trees. Forest Ecology and Management 168:275-287.

Janzen, D.H., 1988. Guanacaste National Park: tropical ecological and biocultural restoration. In Rehabilitating Damaged Ecosystems, Vol. II, ed. J. J. Cairns, pp. 143-192. Boca Raton, FL: CRC Press.

Jones, F. A., Peterson, C. J., and Haines, B. L. 2003. Seed predation in neotropical pre-montane pastures: Site, distance, and species effects. Biotropica 35(2):219-225.

Kammesheidt, L. 1999. Forest recovery by root suckers and above-ground sprouts after slashand-burn agriculture, fire and logging in Paraguay and Venezuela. Journal of Tropical Ecology 15:143-157.

Kennard, D. K. 2002. Secondary forest succession in a tropical dry forest: patterns of development across a 50-year chronosequence in lowland Bolivia. Journal of Tropical Ecology 18:53-66.

Kennard, D. K., Gould, K., Putz, F. E., Fredericksen, T. S., and Morales, F. 2002. Effect of disturbance intensity on regeneration mechanisms in a tropical dry forest. Forest Ecology and Management 162:197-208.

Krejci, L. C., Fortunato, F. F., and Côrrea, P. R. S. 1982. Pedologia - Levantamento exploratório de solos. In Projeto RADAMBRASIL Folha SD. 23 Brasília; geologia, geomorfologia, vegetação e uso potencial da terra. Ministério de Minas e Energia, Secretária-Geral, Vol. 29, ed. H. H. Moreira, p. 660. Brasil: Rio de Janeiro..

Lieberman, D., and Li, M. G. 1992. Seedling recruitment patterns in a tropical dry forest in Ghana. Journal of Vegetation Science 3(3):375-382.

Loik, M. E., and Holl, K. D. 1999. Photosynthetic responses to light for rainforest seedlings planted in abandoned pasture, Costa Rica. Restoration Ecology 7:382-391.

Marod, D., Kutintara, U., Tanaka, H., and Nakashizuka, T. 2002. The effects of drought and fire on seed and seedling dynamics in a tropical seasonal forest in Thailand. Plant Ecology 161:41-57.

McLaren, K. P., and McDonald, M. A. 2003. Coppice regrowth in a disturbed tropical dry limestone forest in Jamaica. Forest Ecology and Management 180:99-111.

Meiners, S. J., and LoGiudice, K. 2003. Temporal consistency in the spatial pattern of seed predation across a forest — old field edge. Plant Ecology 168:45-55.

Melo, V. A., Griffith, J. J., Marco Júnior, P., Silva, E., Souza, A. L., Guedes, M. C., and Ozório, T. F. 2000. Efeito de poleiros artificiais na dispersão de sementes por aves. Revista Árvore 24(3):235-240.

Melo, V. A., Guedes, M. C., and Griffith, J. J. 1997. O Uso de Poleiros artificiais para atração de aves dispersoras de sementes em áreas degradadas.Ararajuba 5(2):229-232.

Murphy, P. G., and Lugo, A. E. 1995. Dry forests of central America and the Caribbean. In Seasonally Tropical Forests, ed. H. A. Mooney and S. H. Bullock, pp. 9-34. Cambridge: University of Cambridge Press.

Myster, R. W. 1997. Seed predation, disease and germination on landslides in neotropical lower montane wet forest. Journal of Vegetation Science 8(1):55-64.

Myster, R. W. 2002. Foliar pathogen and insect herbivory effects on two landslide trees in Puerto Rico. Forest Ecology and management 169:231-242.

Myster, R. W. 2003. Effects of species, density, patch-type, and season on post-dispersal seed predation in a Puerto Rican pasture. Biotropica 35(4):542-546.

Myster, R. W. 2004a. Regeneration filters in post-agricultural fields of Puerto Rico and Ecuador. Plant Ecology 172(2):199-209.

Myster, R. W. 2004b. Post-agricultural invasion, establishment, and growth of neotropical trees. Botanical Review 70:381-402.

Negreros-Castillo, P., Snook, L., and Mize, C. W. 2003. Regenerating mahogany (Swietenia macrophylla) from seed in Quintana Roo, Mexico: the effects of sowing method and clearing treatment. Forest Ecology and Management 183(1-3):351-362.

Nepstad, D. C., Uhl, C., and Serrão, E. A. S. 1990. Surmounting barriers to forest regeneration in abandoned, highly degraded pastures: a case study from Paragominas, Pará, Brazil. 
In Alternatives to deforestation: steps toward sustainable use of the Amazon rain forest, ed. A. B. Anderson, pp. 215-229. New York, USA: Columbia University Press.

Nepstad, D. C., Uhl, C., Pereira, C. A., and da Silva, J. M. C. 1996. A comparative study of tree establishment in abandoned pasture and mature forest of eastern Amazonia. Oikos 76(1): 25-39.

Oliveira-Filho, A. T., and Ratter, J. 1995 A study of the origin of central brazilian forests by the analysis of plant species distribution patterns. Edinb. J. Bot. 52(2):141-194.

Osunkoya, O. O. 1994. Postdispersal survivorship of North Queensland rainforest seeds and fruits: effects of forest, habitat and species. Australian Journal of Ecology 19:52-64.

Posada, J. M., Aide, T. M., and Cavelier, J. 2000. Cattle and weedy shrubs as restoration tools of tropical montane rainforest. Restoration Ecology 8:370-379.

Price, M. V., and Jenkins, S. H. 1986. Rodents as seed consumers and dispersers. In Seed Dispersal, ed. D. R. Murray, pp. 191-235. Sidney, Australia: Academic Press.

Putz, F. E., and Canham, C. D. 1992. Mechanisms of arrested succession in shrublands: root and shoot competition between shrubs and tree seedlings. Forest Ecology and Management 49:267-275.

Ray, G. J., and Brown, B. J. 1995. Restoring Caribbean dry forests: evaluation of tree propagation techniques. Restoration Ecology 3:86-94.

Saha, S., and Howe, H. F. 2003. Species composition and fire in a dry deciduous forest. Ecology $84: 3118-3123$.

Sampaio, E., Salcedo, I. H., and Kauffman, J. B. 1993. Effect of different fire severities on coppicing of Caatinga vegetation in Serra Talhada, PE, Brazil. Biotropica 25:452-460.

Sampaio, A. B., Holl, K. D., and Scariot, A. 2007. Does restoration enhance regeneration of seasonal deciduous forests in pastures in central Brazil? Restoration Ecology 15:462-471.

Sampaio, A. B., Holl, K. D., and Scariot, A. In press b. Regeneration of Seasonal Deciduous Forest Tree Species in Long-Used Pastures in Central Brazil. Biotropica.

Sanchez-Azofeifa, G. A., Daily, G. C., Pfaff, A. S. P., and Busch, C. 2003. Integrity and isolation of Costa Rica's national parks and biological reserves: examining the dynamics of land-cover change. Biol. Conserv. 109:123-135.

Scariot, A., and Sevilha, A. C. 2005. Biodiversidade, estrutura e conservação de florestas estacionais deciduais no Cerrado. In Cerrado: Ecologia, Biodiversidade e Conservação.Ministerio do Meio Ambiente, p. 439. Brasil: Brasília.

Schaller, M., Schroth, G., Beer, J., and Jimenez, F. 2003. Root interactions between young Eucalyptus deglupta trees and competitive grass species in contour strips. Forest Ecology and Management 179:429-440.

Schupp, E. W. 1995. Seed-seedling conflicts, habitat choice, and patterns of plant recruitment. American Journal of Botany 82:399-409.

Sevilha, A. C., Scariot, A., and Noronha, S. E. 2004. Estado atual da representatividade de unidades de conservação em Florestas Estacionais Deciduais no Brasil. In Silva. A. (Org.) Anais do 55 Congresso Nacional de Botânica (CD-ROM). Viçosa, Minas Gerais, Brasil.

Silva. L. A., and Scariot, A. 2003. Composição florística e estrutura da comunidade arbórea em uma floresta estacional decidual em afloramento calcário (Fazenda São José, São Domingos, GO, bacia do rio Paranã). Acta Bot. Bras. 17(2):305-313.

Sweeney, B. W., Czapka, S. J., and Yerkes, T. 2002. Riparian forest restoration: increasing success by reducing plant competition and herbivory. Restoration Ecology 10:392-400.

Uhl, C., Buschbacher, R., and Serrao, E. A. S. 1988. Abandoned pastures in eastern Amazonia. I. patterns of plant succession. Journal of Ecology 76:663-681.

Vesk, P. A., and Westoby, M. 2004. Sprouting ability across diverse disturbances and vegetation types worldwide. Journal of Ecology 92:310-320.

Vieira, D. L. M. 2006. Regeneração natural de florestas secas: Implicações para a restauração. Dr. Thesis. Departamento de Ecologia, Universidade de Brasília, Brasília, DF, Brazil.

Vieira, D. L. M., and Scariot, A. 2006a. Principles of natural regeneration of tropical dry forests for restoration. Restoration Ecology 14(1):11-20.

Vieira, D. L. M., and Scariot, A. 2006b. Effects of logging, liana tangles and pasture on seed fate of dry forest tree species in Central Brazil. Forest Ecology and Management 230 (1-3):197-205. 
Vieira, D. L. M., Scariot, A., Sampaio, A. B., and Holl, K. D. 2006c. Tropical dry-forest regeneration from root suckers in Central Brazil. Journal of Tropical Ecology 22:353-357.

Wijdeven, S. M. J., and Kuzee, M. E. 2000. Seed availability as a limiting factor in forest recovery processes in Costa Rica. Restoration Ecology 8:414-424.

Woods, K., and Elliott, S. 2004. Direct seeding for forest restoration on abandoned agricultural land in northern Thailand. Journal of Tropical Forest Science 16(2):248-259.

Zahawi, R. A. 2005. Establishment and growth of living fence species: An overlooked tool for the restoration of degraded areas in the tropics. Restoration Ecology 13:92-102.

Zahawi, R. A., and Augspurger, C. K. 1999. Early plant succession in abandoned pastures in Ecuador. Biotropica 31:540-552.

Zimmerman, J. K., Pascarella, J. B., and Aide, T. M. 2000. Barriers to forest regeneration in an abandoned pasture in Puerto Rico. Restoration Ecology 8:350-360. 